Relations industrielles

Industrial Relations

\title{
Ethics in Labour Relations
}

\section{Gaston Cholette}

Volume 3, numéro 2, octobre 1947

URI : https://id.erudit.org/iderudit/1023567ar

DOI : https://doi.org/10.7202/1023567ar

Aller au sommaire du numéro

\section{Éditeur(s)}

Département des relations industrielles de l’Université Laval

ISSN

0034-379X (imprimé)

1703-8138 (numérique)

Découvrir la revue

Citer cet article

Cholette, G. (1947). Ethics in Labour Relations. Relations industrielles /

Industrial Relations, 3(2), 26-27. https://doi.org/10.7202/1023567ar

Tous droits réservés (C Département des relations industrielles de l’Université Laval, 1947
Ce document est protégé par la loi sur le droit d'auteur. L'utilisation des services d'Érudit (y compris la reproduction) est assujettie à sa politique d'utilisation que vous pouvez consulter en ligne.

https://apropos.erudit.org/fr/usagers/politique-dutilisation/ 
soient informés de ce que pensent les organisations professionnelles nationales. Parmi les divers groupements qui composent la nation, les associations ouvrières se classent parmi celles qui comprennent leur rôle et qui se font un devoir d'étudier les divers problèmes de l'heure, tant au point de vue syndical, que social et d'intérêt général, de les discuter et d'en faire part.

Avec la guerre et les développements de la civilisation actuelle, les Syndicats pénètrent de plus en plus dans la vie de la communauté nanationale. Dans l'ordre social comme économique, rien n'est plus résolu sans le concours des syndicats ouvriers. L'évolution du syndicalisme, en ce sens, ne peut étonner personne car il faut avoir à l'esprit que le but primordial du mouvement syndical est d'étudier, de promouvoir et de défendre les intérêts professionnels des travailleurs. Il faut reconnaître dans leurs revendications la poussée d'une force qui monte et qui de par sa nature mê- me doit être intégrée à la vie de la nation.

Nous regrettons de ne pas avoir le compterendu de la convention du Congrès canadien du travail qui représente lui aussi les aspirations d'un grand nombre d'ouvriers canadiens. ${ }^{4}$

Malgré les divergences d'inspiration et de technique d'action, il est à remarquer que nos divers groupes d'ouvriers syndiqués s'entendent sur plusieurs points. S'il en est ainsi, c'est donc dire que ce sont là des besoins très importants dont devraient tenir compte les chefs d'Etat, les chefs d'entreprises et le public pour mieux comprendre les réelles aspirations de la classe ouvrière. Les autres groupements professionnels devraient en faire autant. Ce serait vraiment là la démocratie en oeuvre.

(4) Toujours d'après les mêmes statistiques le Congrès canadien du Travail compte 314,025 membres répartis en 338 sections locales.

\section{ETHICS IN LABOUR RELATIONS}

\section{Gaston CHOLETTE}

To the ordinary bystander who witnesses the evolution of labour relations, the latter seem to consist of a mere series of endless disputes and struggles. However, in reality such is not the fact since in spite of the numerous disputes and sensational developments to which much publicity is given there are fortunately more and more cases of fruitful co-operation and mutual understanding that are worthy of being noted. Nevertheless, despite the endeavours of the religious and edifying influences among the Catholic associations grouping employers and workers, the ideals of justice and charity that should prevail in the economic field in this Province are still far from being reached.

Although labour legislation's purpose is to furnish associations with a status guaranteeing the existence and main features of its functions, as also to ensure the harmonious co-operation of the parties in the settlement of disputes and the negotiation of collective agreements, such legislation is far from proving entirely satisfactory and from establishing social peace by the mere fact of its existence. Many people even claim that certain parts of this legislation obstruct the progress of justice, as the mode of procedure prescribed thereby appears to them as constituting a series of difficulties which might sometimes be used to com- plicate the enforcement and interpretation of the labour laws in existence and to provoke the workers by delaying agreements systematically.

Would it be be preferable to ameliorate this legislation? Obviously, indeed, because it often happens that the power of the law is the only thing capable of bringing certain people to reason. However, does not everyday experience with the labour laws in existence tend to prove that one must not entirely rely on them to obtain satisfactory results, even after such laws have been mended or ameliorated ? Quid leges sine moribus: what are laws worth without morals? The principal «social encyclicals», namely : Quadragesimo Anno and Divini Redemptoris, are so explicit that no Catholic may entertain doubts regarding this question.

Morality : ethics! That is the supreme corrective to the great unrest in industrial relations. As a matter of fact, morality is a term that applies not only to the virtues of temperance and chastity, to the sixth and ninth Commandments, but also to all the other virtues and deeds of man. Morality is therefore relevant to the great social virtues: justice and charity. Then, it is an error to limit the meaning of the word morality so that it may only apply to questions of purity.

Let us now see the manner in which morality 
or ethics should govern the acts and attitudes of all those who play a part in the field of industrial relations. Everywhere, even where employers are not particularly well thought of, one hears it said that workers in general are considerably less competent and have less professional conscientiousness nowadays than formerly. It is also often said that trade-unions should not only strive to obtain rises in wages and paid holidays for their members, but should also endeavour to form competent and conscientious workers who would abide by their agreements and serve their employers satisfactorily. Indeed, doing so would often constitute the best means by which they might obtain justice in the settlement of their claims and win both the public's and their employers' favour. Besides, according to strict commutative justice, employers are entitled to suitable efficiency on the part of their employees during every bit of the time they have the later in their employ. They must also be able to count on the respect of their property and on the possibility of maintaining their establishments and undertakings. Above all, society is entitled to the protection of the commonweal which is seriously endangered when certain extensive strikes affecting the production or distribution of indispensable services or goods are called without sufficient grounds.

On the ather hand, employers cannot be justifield in refusing to better the working conditions of their employees on the plea that the latter will still not work to the full extent of their powers and will never be satisfied. It is also to be noted that, in many instances, a worker does not give the full measure of his productivity because his employer has not succeeded in interesting him in the success of the undertaking. And then, what is by far the worst of all, certain employers who are unwilling to accept the teachings of Christian social doctrine resort to means of all kinds, legal or not, to prejudice the interest of trade-unionism. Very often, and it may even be said that in most cases, such employers are those to be held responsible for the strikes which are so frequently and unjustly imputed to the alleged ill-will of the worker. Such unworthy employers are holding back the progress of sound trade-unionism and are thus indirectly paving the way for communism, an evil that is so unequivocally denounced, at least in the international unions.

It is chiefly during the course of the negotiation of collective agreements or during the settling of grievances that the principles of ethics should be observed by employers and employees alike. If both parties always acted in good faith when they met on such occasions, and if they were always moved by the desire to satisfy the requirements of justice and charity, they would save a great deal of time and avoid much bitterness.

Thus we are led to speak of the ethics of men of law, persons who play a vital part in industrial relations. Their duty is to interpret the law and have not only, its letter but its spirit respected. Therefore, they are to be blamed whenever their effective work in this field merely corresponds to siding with the more powerful contestant instead of upholding Christian ethics and the Church's social doctrine. The law must not be considered, even by them, as a means to protect the interests of one party at the expense of the superior rules of justice. Their duties consists chiefly in helping the litigating parties to follow the procedure required and not in indulging in schemes intended to achieve by-passing or restrictive interpretation of the law. Naturally it would be utterly unethical to foster and aggravate disputes without regard for justice and social peace, by multiplying legal difficulties for mere personal profit.

Finally, since the State is invested with authority, and because it is responsible for the public weal, its duty in the field of industrial relations is to facilitate the advent of a Christian order. In its executive and legislative activities it must draw its inspiration from the demands of justice and charity and not from restrictive and antiquated legalism. The State must endeavour to prevent industrial relations from worsening and from thus constituting a grave danger to the welfare of society; it must also adopt a progressive policy and distinguish between foreign tendencies directed against law and order and the activities of the various Catholic associations whose object is the firm establishment of justice. The State is therefore an impartial arbitrator; it must not generalize accusations of communism and raise such accusations againts only one of the parties involved and must never apply such a term to labours' legitimate endeavours to ameliorate its organization and have its rights respected.

D'une simple question de relations interprofessionnelles relevant de la psychologie du commandement et de la compréhension humaine qu'ils étaient au départ, - les rapports professionnels sont devenus de plus en plus un véritable problème intéressant toute la collectivité dont ils semblent devoir conditionner chaque jour davantage l'équilibre social tout entier.

(Droit Social, 1947)
Gérard DEhove 